\title{
ALAT PERAGA PEMBELAJARAN OPERASI HITUNG BILANGAN BULAT \\ DI TINGKAT SEKOLAH DASAR
}

\author{
Suparni
}

Institut Agama Islam Negeri Padangsidimpuan

E-mail: suparbejo@yahoo.com

\begin{abstract}
Mathematicts is an important subject at Elementary Schools. Preliminary observation at many Elementary School indicated that mathematic achievement's students was not satisfactory. The student's understanding of number operations was olso low. One of many ways to improve the student's activities and mathematic achievement is through the use of block Dienes in teaching number operations.
\end{abstract}

Kata kunci : alat peraga blok dienes, pembelajaran operasi hitung bilangan bulat

\section{PENDAHULUAN}

Alat peraga pembelajaran matematika adalah sebuah atau seperangkat benda kongkrit yang dibuat, dirancang, dihimpun atau disusun secara sengaja, yang digunakan untuk membantu menanamkan atau mengembangkan konsep-konsep atau prinsip-prinsip dalam matematika. Dengan alat peraga blok dienes, maka hal-hal yang abstrak dapat disajikan dalam bentuk model-model, sehingga siswa dapat memanipulasi objek tersebut dengan cara dilihat, dipegang, diraba, diputarbalikkan, agar lebih mudah memahami matematika.

Matematika adalah suatu ilmu yang berhubungan dengan bentuk-bentuk suatu struktur yang abstrak dan hubungan diantara hal-hal tersebut. Untuk dapat memahaminya, diperlukan pemahaman tentang konsep-konsep yang terdapat dalam matematika. Karena sifatnya yang abstrak,maka dalam pembelajaran matematika masih diperlukan benda-benda yang menjadi perantara atau alat peraga blok 
dienes yang berfungsi untuk mengkongkritkan sehingga fakta-faktanya lebih jelas dan lebih mudah diterima oleh siswa. Oleh karena itu wajar jika matematika tidak mudah difahami oleh kebanyakan siswa usia sekolah dasar.

Berdasarkan hal tersebut di atas untuk memahami suatu konsep matematika, siswa masih harus diberikan rangkaian kegiatan nyata yang dapat diterima akal mereka. Dengan demikian alat bantu belajar atau biasa disebut media sangatlah diperlukan dalam pembelajaran matematika, untuk memberikan pengalaman belajar yanag bermakna, mengaktifkan dan menyenangkan.

Siswa tidak akan mendapat kesulitan dalam memahami konsep apabila dalam pembelajarannya dibantu oleh alat peraga blok dienes manipulatif. Manipulasi dan model adalah alat yang sangat penting untuk membuat siswa dalam mengkomunikasikan ide dan konsep matemataika.

Alat peraga blok dienes merupakan bagian dari media pembelajaran yang diartikan sebagai semua benda sebaga perantara di mana digunakan dalam proses pembelajaran. Tujuan penggunaan media pembelajaran pada prinsipnya adalah untuk memperjelas instrumen yang disampaikan, dapat merangsang pikiran, perhatian, dan kemampuan siswa, harus dapat meningkatkan efektifitas dan kelancaran proses pembelajaran, terutama dalam memperjelas materi yang sedang dipelajari.

Penggunaan benda manipulasi dan model matematika mempunyai keuntungan seperti gambar yang mengandung ribuan kata, manipulasi dapat menyajikan ide secara visual, membantu siswa untuk tahu dan mengerti. Manipulasi meningkatkan kemampuan siswa pada semua tingkatan, untuk mempertimbangkan dan mengkomunikasikan. Belajar dengan manipulasi dapat meningkatkan pemahaman konsep dan hubunganketrampilan praktek yang berarti, meningkatkan ingatan.

Dalam memilih jenis alat peraga blok dienes blok dienes haruslah disesuaikan dengan topik materi yang akan diajarkan dan juga tingkat perkembangan siswa. Menurut Bruner, dalam proses pembelajaran siswa melalui tiga tahapan, yaitu tahaf Enaktif, Ikonik dan Simbolik. Pada tahapan Enaktif siswa secara langsung terlibat dalam memanipilasi objek blok dienes. Pada tahap Ikonik, kegiatan yang dilakukan siswa berhubungan dengan mental yang merupakan gambaran objek-objek yang dimanipulasi siswa. Siswa tidak lagi langsung memanipulasi objek benda seperti yang dilakukan pada tahap Enaktif. Sedangkan pada tahap yang terahir yaitu Simbolik, siswa memanipulasi simbol-simbol atau lambanglambang objek tertentu. Siswa tidak lagi terikat dengan objek-objek pada tahap sebelumnya.

Alat peraga blok dienes ini dapat saja berupa benda nyata atau dapat juga berupa gambar. Keuntungan daripada penggunaan alat peraga blok dienes ini adalah bahwa alat tersebut dapat dikotakkatik, depegang, diraba, dipindah-pindahkan atau dimanipulasi, Cuma saja kekurangannya adalah bahwa 
blok dienes tersebut tidaklah dapat disajikan dalam bentuk tulisan atau buku. Manfaat lain dari demontrasi blok dienes dalam pembelajaran matematika adalah bahwa siswa akan lebih gembira dalam belajar, lebih dapat memahami dan mengerti materi yang dipelajari dan pada akhirnya akan disadari bahwa ternyata ada hubungan yang sangat erat antara benda-benda di sekitarnya dengan konsep matematika yang abstrak itu.

Siswa yang taraf berpikirnya masih berada pada tahap operasional konkrit (7-13 th) belum dapat memahami operasi logis dalam konsep matematika tanpa dibantu oleh benda-blok dienes. Dalam setiap proses pembelajaran sebaiknya siswa diberikan kesempatan untuk memanipulasi benda-blok dienes. Melalui kegiatan ini siswa akan dapat melihaat langsung bagaimana ketentuan-ketentuan serta pola-pola yang terdapat benda tersebut.

Alat peraga blok dienes harus dibuat sebaik mungkin, menarik untuk dipahami, dan mendorong siswa untuk bersifat penasaran (curious), sehingga diharapkan motivasi belajarnya semakin meningkat. Alat peraga blok dienes juga diharapkan menumbuhkan daya imajinasi dalam diri siswa. Misalnya alat peraga blok dienes benda-benda ruang dapat mendorong siswa dalam meningkatkan daya tilik ruangnya, mampu membandingkannya dengan benda-benda sekitar dalam lingkungannya sehari-hari, dan mampu menganalisis sifat-sifat benda yang dihadapinya itu.

\section{PEMBAHASAN}

\section{Hakekat Matematika}

James dan James (1976) dalam kamus matematikanya mengatakan bahwa matematika adalah ilmu tentang logika mengenai bentuk, susunan, besaran dan konsep-konsep yang saling berhubungan satu dengan lainnya dengan jumlah yang banyaknya terbagi ke dalam tiga bidang, yaitu aljabar, analisis dan geometri. Namun pembagian yang jelas sangatlah sukar untuk dibuat, sebab cabangcabang itu semakin bercampur. Sebagai contoh ada pula yang berpendapat bahwa matematika itu timbul karena pikiran-pikiran manusia yang berhubungan dengan ide, proses dan penalaran yang terbagi menjadi empat wawasan yang luas, yaitu aritmatika, aljabar, geometri dan analisis, dengan aritmatika mencakup teori bilangan dan statistik.

Berbagai pendapat muncul tentang pengertian matematika. Ada yang mengatakan bahwa matematika itu bahasa simbol; matematika adalah bahasa numeric; matematika adalah bahasa yang 
dapat menghilangkan sifat kabur, majemuk dan emosional; matematika adalah metode berpikir logis; matematika adalah sarana berpikir; matematika adalah sains mengenai kuantitas dan besaran; matematika adalah suatu sains yang bekerja menarik kesimpulan-kesimpulan yang perlu; matematika adalah sains formal yang murni; matematika adalah sain yang memanipulasi symbol; matematika adalah ilmu tentang bilangan dan ruang; matematika adalah ilmu yang mempelajari tentang hubungan pola, bentuk dan struktur; matematika adalah ilmu yang abstrak dan deduktif dan matematika adalah aktivitas manusia.

Johnson dan Rising dalam Ruseffendi (1992) mengatakan bahwa matematika adalah pola berpikir, pola mengorganisasikan pembuktian yang logik; matematika itu adalah bahasa yang menggunakan istilah yang didefenisikan dengan cermat, jelas dan akurat, representasinya dengan simbol dan padat, lebih berupa bahasa simbol mengenai ide (gagasan) daripada mengenai bunyi; matematika adalah pengetahuan struktur yang terorganisasikan sifat-sifat atau teori-teori itu dibuat secara deduktif berdasarkan kepada unsur-unsur yang didefenisikan atau tidak didefenisikan, aksioma-aksioma, sifat-sifat atau teori-teori yang telah dibuktikan kebenarannya; matematika adalah ilmu tentang pola, keteraturan pola atau ide; dan matematika itu adalah seni, keindahannya terdapat pada keteraturan dan keharmonisannya. Jadi menurut Johnson Rising, jelas bahwa matematika adalaah ilmu deduktif.

\section{Karakteristik Pembelajaran Matematika di Sekolah Dasar (SD)}

Pembelajaran matematika di Tingkat SD merupakan salah satu kajian yang menarik untuk dikemukakan hal ini disebabkan oleh karena adanya perbedaan karakteristik khususnya antara hakekat anak dengan hakekat matematika. Untuk itu diperlukan adanya jembatan yang dapat menetralisir perbedaan atau pertentangan tersebut. Anak yang berada pada usia SD sedang mengalamai perkembangan dalam tingkat berpikirnya. Tahap berpikir mereka masih belum formal, malahan para siswa SD di kelas-kelas rendah (kelas I, II dan III) bukan tidak mungkin sebagian dari mereka berpikirnya masih berada pada tahapan pra kongkrit.

Jean Peaget dengan teori belajar yang disebut Teori Perkembangan Mental Anak atau ada pula yang menyebutnya Teori Tingkat Perkembangan Berpikir Anak telah membagi tahapan kemampuan berpikir anak menjadi empat tahapan, yaitu tahap sensori matorik (dari lahir sampai usia 2 tahun), tahap operasional awal/praoperasi (usis 2 sampai 7 tahun), tahap operasional/operasi 
kongkrit (usia 7 sampai 11 atau 12 tahun) dan tahap operasioanl formal/operasi formal (usia 11 tahun ke atas).

Di sisi lain, berkenaan dengan karakteristik matematika, bahwa matematika adalah ilmu deduktif, abstrak, menggunakan bahasa simbol yang padat arti dan semacamnya. Mengingat adanya perbedaan karakteristik itu, maka diperlukan adanya kemampuan khusus dari seorang guru untuk menjembatani antara dunia anak yang belum berpikir secara deduktif untuk dapat mengerti dunia matematika yang bersifat deduktif.

Anak usia SD pada umumnya berada pada tahap berpikir operasional kongkrit, namun tidak menutup kemungkinan mereka masih berada pada tahap praoperasi. Sedangkan pada setiap tahapan ada ciri-cirinya sesuai umur kesiapannya. Misalnya, bila anak berada pada tahap praoperasi maka mereka belum memahami hukum-hukum kekekalan, sehingga bila diajarkan konsep penjumlahan besar kemungkinan mereka tidak akan mengerti. Siswa yang berada pada tahap operasi kongkrit memahami hukum kekekalan, tetapi ia belum bisa berpikir secara deduktif, sehingga pembuktian dalil-dalil matematika tidak akan dimengerti oleh mereka. hanya anak-anak yang berada pada tahapan operasi formal yang bisa berpikir secara deduktif.

Melihat secara singkat dari teori belajar Peaget ini tentunya kita dapat mengambil manfaatnya dalam pembelajaran matematika khususnya di tingkat SD yaitu, terutama tentang kesiapan untuk belajar dan bagaimana berpikir mereka itu berubah sesuai dengan perkembangan usianya. Hal ini berarti bahwa strategi pembelajaran matematika yang kita gunakan haruslah sesuai dengan perkembangan intelektual atau perkembangan tingkat berpikir anak, sehingga diharapkan pembelajaran matematika di Tingkat SD itu lebih efektif dan lebih hidup.

Jadi, pada dasarnya agar pelajaran matematika di Tingkat SD itu dapat dimengerti oleh para siswa dengan baik, maka seyogyanya mengajarkan sesuatu bahasan itu harus diberikan kepada siswa yang sudah siap untuk menerimanya. Anak itu bukanlah tiruan dari orang dewasa. Anak bukan bentuk mikro dari orang dewasa. Anak-anak mempunyai kemampuan intelektual yang sangat berbeda dengan orang dewasa. Cara-cara berpikir anak berbeda dengan cara-cara berpikir orang dewasa.

Jerome S. Bruner menjadi terkenal dalam dunia pendidikan khususnya pendidikan matematika. Ia telah menulis hasil studinya tentang "perkembangan belajar", yang merupakan suatu cara untuk mendefenisikan belajar. Bruner menekankan bahwa setiap individu pada waktu mengalami atau mengenal peristiwa atau benda di dalam lingkungannya, menemukan cara 
untuk menyatakan kembali peristiwa atau benda tersebut di dalam pikirannya, yaitu suatu model mental tentang peristiwa atau benda yang dialaminya atau dikenalnya.

Menurut Bruner, hal-hal tersebut dapat dinyatakan sebagai proses belajar yang terbagi menjadi tiga tahapan, yaitu:

\section{a. Tahap Enaktif atau tahap Kegiatan (Enactive)}

Tahap pertama anak belajar konsep adalah berhubungan dengan benda-benda real atau mengalami peristiwa di dunia sekitarnya. Pada tahap ini anak masih dalam gerak refleks dan coba-coba, belum harmonis. Ia memanipulasikan, menyususun, menjejerkan, mengutak-atik, dan bentuk-bentuk gerak lainnya (serupa dengan tahap sensori motor dari Peaget)

b. Tahap Ikonik atau Tahap Gambar Bayangan (Iconic)

Pada tahap ini, anak telah mengubah, menandai dan menyimpan peristiwa atau benda dalam bentuk bayangan mental. Dengan kata lain anak dapat membayangkan kembali atau memberikan gambaran dalam pikirannya tentang benda atau peristiwa yang dialami atu dikenalnya pada tahap enaktif, walaupun peristiwa itu telah berlalu atau benda real itu tidak lagi berada di hadapannya (tahap praoperasi dari Peaget)

Jika kita memperhatikan proses pembelajaran matematika yang berlangsung sehari-hari di Tingkat SD, menurut Karso (2006: 1.48) maka pada dasarnya kegiatan belajar mengajar matematika tersebut dapat dikelompokkan menjadi tiga tahapan pokok. ketiga tahapan itu meliputi kegiatan pembelajaran untuk penanaman konsep, kegiatan pembelajaran untuk pemahaman konsep, dan kegiatan pembelajaran untuk pembinaan ketrampilan.

Dalam model pembelajaran dengan pendekatan penanaman konsep ini tujuan utama kegiatannya adalah untuk menyampaikan konsep-konsep baru yang umumnya merupakan jenis konsep dasar. Dalam menanamkan konsep baru ini tentunya kita harus memperhatikan kaitannya dengan konsep-konsep prasarat, penggunaan alat bantu pelajaran, disajikan dengan pengkontrasan dan keanekaragaman, memperhatikan kemampuan berpikir anak, dan berpegang teguh pada hakekat matematika.

Model pembelajaran dengan pendekatan pemahaman konsep adalah proses kegiatan belajar mengajar yang merupakan kelanjutan dari model pendekatan penanaman konsep. Dalam pemahaman konsep proses pembelajarannya memberi penekanan supaya para siswa menguasai ciri-ciri, sifat-sifat dan penerapan dari konsep yang telah dipelajarinya pada tahap penanaman konsep. Oleh karena itu 
dalam menyusun rencana kegiatan pembelajaran pemahaman konsep ini harus mengungkapkan penggunaan atau penguasaan konsep-konsep yang telah dipelajari pada tahap penanaman konsep.

Proses pembelajaran di sekolah pada dasarnya adalah proses komunikasi, yaitu proses penyampaian pesan dari sumber pesan melalui saluran tertentu kepada penerima pesan. Pesan yang akan dikomunikasikan adalah isi ajaran atau didikan yang ada dalam kurikulum. Sumber pesannya adalah guru dan penerima pesannya adalah siswa. Dalam proses komunikasi pembelajaran tersebut adakalanya terjadi kegagalan dalam menafsirkan pesan-pesan yang disebabkan oleh berbagai hambatan dan pada akhirnya mengakibatkan proses pembelajaran berlangsung secra tidak efektif dan efisien. Untuk mengatasinya sardiman, dkk (1996:14) menyarankan pemakaian media pembelajaran sebagai salah satu sumber belajar yang dapat menyalurkan pesan yang berupa isi ajaran atau didikan yang ada dalam kurikulum. Lebih lanjut dikatakan bahwa perbedaan gaya belajar, minat, intelegensi, keterbatasan gaya indera dapat dibantu mengatasinya dengan pemanfaatan media pembelajaran.

Menurut Sardiman, dkk (1996) media adalah segala sesuatu yang dapat digunakan untuk menyalurkan pesan dari pengirim ke penerima, sehingga merangsang pikiran, perasaan, perhatian dan minat serta perhatian siswa sehingga terjadi proses belajar.

Bruner (1966: 10 - 11) menyatakan ada tiga tingkatan utama modus belajar, yaitu pengalaman langsung (enactif), pengalaman pictorial/ gambar (iconic), dan pengalaman abstrak (symbolic). Ketiga pengalaman ini saling berinteraksi dalam upaya memperoleh pengalaman (pengetahuan, sikap dan ketrampilan).

Tingkatan pengalaman perolehan hasil belajar seperti itu digambarkan oleh Dale (1969) sebagai suatu proses komunikasi. Materi yang ingin disampaikan dan diinginkan siswa hingga dapat dikuasainya disebut sebagai pesan. Guru sebagai sumber pesan menuangkan pesan ke dalam simbolsimbol tertentu (econding) dan siswa sebagai penerima pesan menafsirkan simbol-simbol tersebut sehingga dipahami sebagai pesan (deconding).

Berdasarkan teori mengenai media di atas, dapat diketahui bahwa pemanfaatan media dalam pembelajaran dapat membawa dampak yang baik dimana media dapat menjadikan kelas interaktif, mempermudah memahami yang abstrak dan menambah motivasi siswa dalam belajar sebagaimana dikemukakan oleh Hamalik (1986) bahwa pemakaian media pengajaran dalam proses belajar mengajar dapat membangkitkan keinginan dan minat baru.

Seorang ahli psikologi Bruner menyatakan bahwa bagi anak berumur antara 7 sampai 17 tahun, untuk mendapatkan daya tangkap dan daya serapnya yang meliputi ingatan, pemahaman dan 
penerapan masih memerlukan mata dan tangan. Mata berfungsi untuk mengamati sedangkan tangan berfungsi untuk meraba. Dengan demikian dalam pendidikan matematika, dituntut adanya "bendablok dienes yang merupakan model dari ide-ide matematika" yang disebut alat peraga.

\section{ALAT PERAGA DALAM PEMBELAJARAN MATEMATIKA}

Pada dasarnya anak belajar melalui benda/objek kongkrit. Untuk memahami konsep abstrak anak memerlukan benda-benda kongkrit (riil) sebagai perantara atau visualisasinya. Selanjutnya konsep abstrak yang baru dipahami siswa itu akan mengendap, melekat, dan bertahan lama bila siswa belajar melalui perbuatan dan dapat dimengerti siswa, bukan melalui mengingat-ingat fakta.

Salah satu peranan alat peraga dalam matematika adalah meletakkan ide-ide dasar konsep. Dengan bantuan alat peraga yang sesuai, siswa dapat memahami ide-ide dasar yang melandasi sebuah konsep, mengetahui cara membuktikannya suatu rumus atau teorema, dan dapat menarik suatu kesimpulan dari hasil pengamatannya.

Setelah siswa mendapat kesempatan terlibat dalam proses pengamatan dengan bantuan alat peraga, maka dapat diharapkan akan tumbuh minat belajar matematika pada dirinya, dan akan menyenangi konsep yang disajikan, karena sesuai dengan tahap perkembangan mentalnya, yang masih menyenangi permainnan.

Selain tumbuhnya minat, siswa juga dapat dibangkitkan motivasinya. Melalui demontrasi penggunaan alat peraga matematika, guru dapat merangsang munculnya motivasi dalam diri siswa untuk mempelajari materi lebih lanjut. Siswa yang merasa penasaran dan ingin tahu lebih jauh tentang konsep yang dipelajarinya akan terus berusaha mempelajari konsep itu lebih mendalam.

Selain itu, pembelajaran dengan menggunakan alat peraga akan dapat memperbesar perhatian siswa terhadap pembelajaran yang dilangsungkan, karena mereka terlibat dengan aktif dalam pembelajaran yang dilaksanakan. Dengan bantuan alat peraga konsentrasi belajar dapat lebih ditingkatkan. Alat peraga dapat pula membantu siswa untuk berpikir logis dan sistematik, sehingga mereka pada akhirnya memiliki pola pikir yang diperlukan dalam mempelajari matematika.

Dengan bantuan alat peraga matematika, siswa akan semakin mudah memahami hubungan antara matematika dan lingkungan alam sekitar. Siswa akan semakin mudah memahami kegunaan matematika dalam kehidupan sehari-hari. Diharapkan, dengan adanya kesadaran seperti ini, mereka terdorong untuk mempelajari matematika lebih lanjut. Misalnya dengan penggunaan alat peraga 
dalam penjelasan konsep ruang berdimensi tiga siswa akan semakin terlatih daya tilik ruangnya, sehingga pada akhirnya mampu menemukan atau menyadari hubungan antara matematika dengan lingkungan sekitar.

Penggunaan alat peragaharus dilaksanakan secara cermat, jangan sampai konsep menjadi lebih rumit akibat pelaksanaan alat peragadengan bantuan alat peraga. Demontrasi dengan bantuan alat peraga harus dilakukan secara tepat, disesuaikan dengan sifat materi yang disampaikan, metode pengajaran yang digunakan dan tahap perkembangan mental anak.

Penggunaan alat peraga harus mampu menghasilkan generalisasi atau kesimpulan abstrak dari representasi kongkrit. Maksudnya, dengan bantuan alat peraga yang sifatnya kongkrit, siswa diharapkan mampu menarik kesimpulan.

Alat peraga yang digunakan tanpa persiapan bisa mengakibatkan habisnya waktu dan sedikitnya materi yang dapat disampaikan. Jika ini yang terjadi, maka dapat dikatakan bahwa alat peraga yang kita pakai atau cara penggunaan alat peraga yang kita lakukan tidak mencapai sasaran. Konsep yang menjadi semakin rumit untuk dipahami sebagai akibat digunakannya alaat peraga, adalah suatu hal yang keliru. Tidak semua alat peragaharus menyertakanalat peraga dalam proses pembelajaran, penggunaan alat peraga tidak harus dipaksakan, sebab alat peraga pada hakekatnya tidak harus digunakan untuk setiap penjelasan topi-topik dalam matematika. Alat peraga yang akan dipergunakan dalam alat peragapada tulisan ini adalah alat peraga blok dienes untuk menjelaskan konsep operasi hitung (p77uuenjumlahn, pengurangan, perkalian dan pembagian) pada bilangan bulat yaitu blok Dienes.

Untuk mengajarkan operasi hitung pada bilangan bulat, perlu disiapkan benda-benda kongkrit, mengingat siswa SD yang duduk di kelas 1 sampai kelas 3 masih berada pada taraf berpikir operasional kongkrit. Benda-benda kongkrit yang disiapkan dapat berupa benda nyata yang ada disekitar lingkungan sekolah atau daerah sekolah, maupun benda-benda model kongkrit yang dibuat untuk keperluan mengajarkan operasi hitung. Benda-benda tersebut antara lain: lidi, tusuk gigi/sate, batang korek api, timbangan bilangan, mistar hitung, batang cuisenaire dan blok Dienes.

\section{Alat Peraga Blok Dienes dalam Pembelajaran Operasi Hitung Bilangan Bulat}

Blok Dienes atau kubus Unifik dikembandangkan oleh Z.P. Dienes yang bertujuan untuk memahami konsep dasar bilangan dan nilai tempat. Blok model Dienes ini dapat dibuat dari balok 
kayu dan dapat juga digunakan untuk memperkenalkan konsep operasi hitung pada bilangan bulat dengan angka-angka yang besar. Untuk bilangan dasar 10, blok Dienes terdiri atas batang satuan (berupa kubus kecil), batang puluhan (berupa batang), batang ratusan (berupa balok) dan batang ribuan (berupa kubus yang lebih besar). Batang satuan berbentuk kubus dengan ukuran $1 \mathrm{~cm} \times 1 \mathrm{~cm} x$ $1 \mathrm{~cm}$, batang puluhan berbentuk balok yang besarnya sama dengan sepuluh batang satuan yang dijadikan satu, sehingga memanjang dengan dimensi $10 \mathrm{~cm} \times 1 \mathrm{~cm} \times 1 \mathrm{~cm}$. Batang ratusan berbentuk balok yang besarnya sama dengan sepuluh batang puluhan yang digabung menjadi satu, sehingga memanjang dengan dimendi $10 \mathrm{~cm} \times 10 \mathrm{~cm} \times 1 \mathrm{~cm}$. Batang ribuan berbentuk kubus yang besarnya sama dengan sepuluh buah batang ratusan dikumpulkan menjadi satu dengan dimensi $10 \mathrm{~cm} \times 10 \mathrm{~cm} x$ $10 \mathrm{~cm}$.

Alat peraga blok dienes blok Dienes ini memiliki beberapa keunggulan dibandingkan dengan beberapa alat peraga blok dienes pembelajaran lainnya. Beberapa keunggulan alat peraga blok dienes ini misalnya : mudah dalam memperoleh atau membuatnya, dapat dibuat dari bahan yang mudah didapatkan disekitar rumah atau lingkungan sekolah dan tidak memerlukan biaya yang tinggi dalam pembuatannya. 

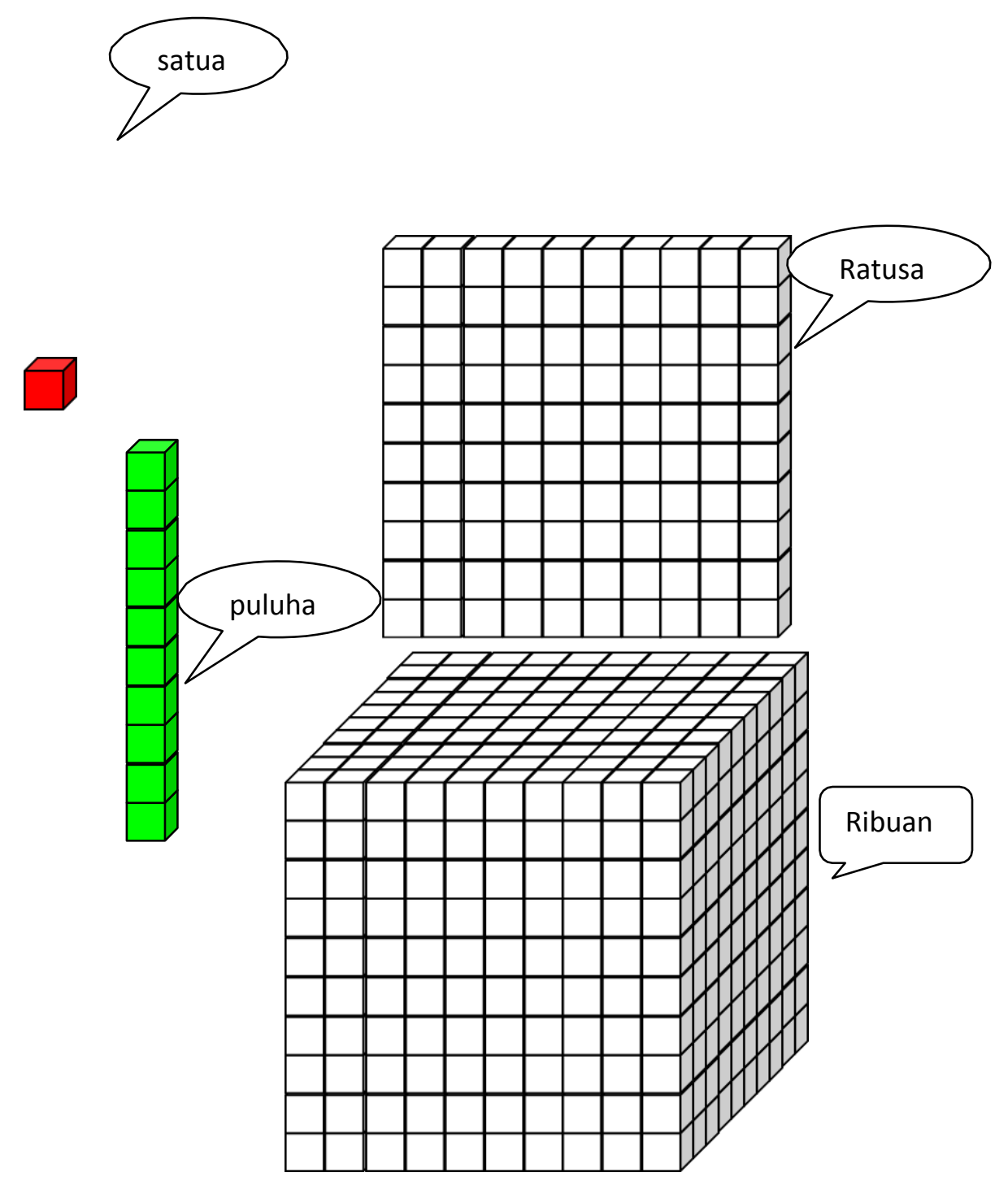
Alat peraga blok dienes blok model Dienes ini dapat dibuat dari balok kayu dan digunakan untuk memperkenalkan konsep operasi hitung pada bilangan bulat dengan angka-angka yang besar. Untuk bilangan dasar 10, blok Dienes terdiri atas batang satuan (berupa kubus kecil), batang puluhan (berupa batang), batang ratusan (berupa balok) dan batang ribuan (berupa kubus yang lebih besar). Batang satuan berbentuk kubus dengan ukuran $1 \mathrm{~cm}$ x $1 \mathrm{~cm}$ x $1 \mathrm{~cm}$, batang puluhan berbentuk balok yang besarnya sama dengan sepuluh batang satuan yang dijadikan satu, sehingga memanjang dengan dimensi $10 \mathrm{~cm} \times 1 \mathrm{~cm} \times 1 \mathrm{~cm}$. Batang ratusan berbentuk balok yang besarnya sama dengan sepuluh batang puluhan yang digabung menjadi satu, sehingga memanjang dengan dimensi $10 \mathrm{~cm} \mathrm{x} 10 \mathrm{~cm} \mathrm{x}$ $1 \mathrm{~cm}$. Batang ribuan berbentuk kubus yang besarnya sama dengan sepuluh buah batang ratusan dikumpulkan menjadi satu dengan dimensi $10 \mathrm{~cm} \times 10 \mathrm{~cm} \times 10 \mathrm{~cm}$.

Sebagai contoh penggunaan alat peraga blok dienes blok Dienes ini pada operasi hitung dijelaskan sebagai berikut.

$658+564=\ldots \ldots$

Bilangan 658 dapat direpresentasikan dengan 6 buah blok ratusan, 5 buah blok puluhan dan 8 buah blok satuan. Sedangkan bilangan 564 direpresentasikan dengan 5 buah blok ratusan, 6 buah blok puluhan, dan 4 buah blok satuan. Lalu kedua kelompok blok tersebut digabungkan dan selanjutnya dikelompok-kelompokkan sesuai dengan jenisnya yang sama. Akhirnya diperoleh 11 buah blok ratusan, 11 buah blok puluhan dan 12 buah blok satuan. Selanjutnya ingat kembali bahwa 10 buah blok ratusan dapat ditukar dengan 1 buah blok ribuan dan 10 buah blokpuluhan dapat ditukar dengan blok satuan demikian juga 10 buah blok satuan dapat ditukar dengan blok puluhan. Dengan demikian

11 blok ratusan $\quad=1$ blok ribuan +1 blok ratusan

11 blok puluhan $\quad=\quad 1$ blok ratusan +1 blok puluhan

12 blok satuan $\quad=\quad 1$ blok puluhan +2 blok satuan 
Sehingga diperoleh hasil akhir adalah 1 blok ribuan +2 blok ratusan +2 blok puluhan dan 2 blok satuan atau sama dengan 1222 (seribu dua ratus dua puluh dua)

\section{KESIMPULAN}

Berdasarkan hasil tulisan dapat disimpulkan sbb:

1. Pembelajaran matemtika khususnya pada operasi hitung bilangan dengan menerapkan Alat peraga blok Dienes akan dapat meningkatkan minat, pemahaman, kreatifitas dan hasil belajar siswa

2. Beberapa faktor yang juga perlu diperhatikan untuk kelancaran proses pembelajaran dengan menerapkan alat peraga blok dienes antara lain kesiapan guru, pengalaman guru dan variasi metode mengajar yang dimiliki guru. Selain itu juga kelengkapan jenis blok dienes yang tersedia di kelas yang sesuai dengan materi yang akan diajarkan.

Dalam pembelajaran matematika, penggunaan alat peragablok dienes maka :

1. Proses pembelajaran lebih termotivasi. Baik siswa maupun guru, dan terutama siswa, minatnya akan timbul. Ia akan senang, terangsang, tertarik, dan karena itu akan bersikap positif terhadap pengajaran matematika.

2. Konsep abstrak matematika tersajikan dalam bentuk kongkrit dan karena itu lebih dapat dipahami dan dimengerti, dan dapat ditanamkan pada tingkat-tingkat yang lebih rendah.

3. Hubungan antara konsep abstrak matematika dengan benda-benda di alam sekitar akan lebih dapat dipahami.

4. Konsep-konsep abstrak yang tersajikan dalam bentuk kongkrit yaitu dalam bentuk model matematika yang dapat dipakai sebagai obyek tulisan maupun sebagai alat untuk meneliti ide-ide baru dan relasi baru menjadi bertambah banyak 


\section{DAFTAR PUSTAKA}

Abdillah Hanafi. (1988). Prinsip-Prinsip Belajar Untuk Pengajaran. Surabaya: Usaha Nasional. E Mulyasa. (2005). Menjadi Guru Profesional Menciptakan Pembelajaran Kreatif dan Menyenangkan. Bandung : Remaja Rosda Karya

Erman Suherman, dkk. (2003). Strategi Pembelajaran Matematika Kontemporer. Common Textbook. JICA.UPI Bandung.

Ginnis Paul. (2008). Trik dan Taktik Mengajar. Jakarta: Indeks

Howe, Michael J.A. (2005). Memahami Belajar di Sekolah. Alih bahasa H.M. Kaoy Syah. Banda Aceh: Yayasan PeNa

Herman hudoyo. (1988). Belajar Mengajar Matematika. Jakarta: Dirjen Dikti $\mathrm{P}_{2}$ LPTK

Karso,dkk. (2006). Pendidikan Matematika I. PGSD 2303. Modul 1-9. Jakarta : Universitas Terbuka : Indeks

Kaueldt Martha. (2008). Wahai Para Guru, Ubahlah Cara Mengajarmu!. Jakarta Lisnawati Simanjuntak. (1993). Metode Mengajar Matematika. Jakarta : Rineka Cipta. Moh. Uzeer Usman. (2000). Menjadi guru Profesional. Bandung : Remaja Rosda Karya Sardiman. (2006). Interaksi \& Motivasi Belajar Mengajar. Jakarta: Raja Grapindo

Silberman, Melvin L. (2006). Active Learning, 101 Cara Belajar Siswa Aktif. Terjemahan oleh Raisul Muttaqin. Bandung: Nusamedia.

Syaiful Bahri Djamarah.(2002). Psikologi Belajar. Jakarta: Rineka Cipta.

S. Nasution. (1995). Didaktik Asas-Asas Mengajar. Jakarta: Bumi Aksara.

Tri Handoko (2007). Terampil Matematika 2 Untuk Kelas II SD/MI. Bandung: Yudhistira Udin S. Winataputra. (1994). Strategi Belajar Mengajar Matematika. Jakarta: Depdikbud. 